\title{
Bank erosion events and processes in the Upper Severn basin
}

\author{
D.M. Lawler, ${ }^{1}$ J. Couperthwaite, ${ }^{1}$ L.J. Bull ${ }^{2}$ and N.M. Harris ${ }^{1}$ \\ 1 School of Geography, The University of Birmingham, Edgbaston, Birmingham, B15 2TT, UK. (Email, D.M. Lawler@bham.ac.uk) \\ 2 School of Geography, Leeds University, Leeds LS2 9JT
}

\begin{abstract}
This paper examines river bank retreat rates, individual erosion events, and the processes that drive them in the Upper Severn basin, mid-Wales, UK. Traditional erosion pin networks were used to deliver information on patterns of downstream change in erosion rates. In addition, the novel automatic Photo-Electronic Erosion Pin (PEEP) monitoring system was deployed to generate near-continuous data on the temporal distribution of bank erosion and accretion: this allowed focus on the magnitude and timing of individual erosional and depositional events in relation to specific flow episodes. Erosion dynamics data from throughout the Upper Severn basin are combined with detailed information on bank material properties and spatial change in channel hydraulics derived from direct field survey, to assess the relationships between flow properties and bank erosion rates.

Results show that bank erosion rates generally increase downstream, but relate more strongly to discharge than to reach-mean shear stress, which peaks near the basin head. Downstream changes in erosion mechanisms and boundary materials, across the upland/lowland transition (especially the degree of development of composite bank material profiles), are especially significant. Examples of sequences of bank erosion events show how the PEEP system can (a) quantify the impact of individual, rather than aggregated, forcing events, (b) reveal the full complexity of bank response to given driving agents, including delayed erosion events, and (c) establish hypotheses of process-control in bank erosion systems. These findings have important implications for the way in which bank erosion problems are researched and managed. The complex responses demonstrated have special significance for the way in which bank processes and channel-margin sediment injections should be handled in river dynamics models.
\end{abstract}

\section{Introduction}

River bank erosion has important implications for channel adjustment and long-term channel change, meander development, catchment sediment dynamics, riparian land loss and downstream sedimentation problems. However, river bank erosion processes are still poorly understood, and therefore weakly specified in models of river dynamics and sediment transport, and only loosely integrated into river management strategies (e.g. Wang et al., 1997). Downstream changes in retreat rates for individual basins are also poorly documented (but $c f$. Hooke, 1977; 1980). The relationship between flow energy and bank retreat rates is fundamental to these issues, but is complicated by (a) the operation of both fluvial and non-fluvial erosion processes in bank erosion systems (e.g. Thorne, 1982; Lawler, 1992a; Lawler et al., 1997a), (b) the presence of distinct time-lags between process and response in bank erosion systems, and (c) the lack of erosion/accretion information at the event timescale.

In particular, this absence of data on erosion events is problematic with regard to the wider issues of erosion mechanisms, catchment sediment dynamics and bank erosion control. It is well recognised, for example, that a knowledge of sediment supplies is crucial to a full understanding of sediment transport systems. River banks are often key sediment suppliers to fluvial systems (e.g. Duijsings, 1987; Odgaard, 1987; Church and Slaymaker, 1989), but to obtain a complete understanding of river sediment transport processes, information is needed on the magnitude, frequency and timing of the actual sediment injection events from river banks. With current, manual, methods, this is not possible. Thus, the details of the dynamics of bank erosion and deposition episodes, and especially their timing and magnitude in relation to the driving forces, are simply unknown at present. Without this information, at a time resolution comparable to that commonly available for flow and meteorological variables, not only is it difficult to couple effectively the bank sediment supply system with fluvial sediment transport fluxes, it also hinders the identification of the processes and mechanisms of river bank erosion. 
To help address these research lacunae, this paper aims to (i) document downstream changes in bank erosion rates, across the upland/lowland transition, within and below the Plynlimon experimental catchment; (ii) present information on the dynamics of example bank erosion events in relation to individual flow events, using the PhotoElectronic Erosion Pin (PEEP) automatic erosion and deposition monitoring system, and (iii) relate these bank erosion rates and events to downstream changes in river hydraulics and bank material characteristics.

\section{Methods}

\section{STUDY AREA}

Bank erosion research was initiated by the University of Birmingham within the Upper Severn Institute of Hydrology (IH) Plynlimon research catchments because of several advantages. Firstly, it afforded the opportunity of evaluating the performance of the PEEP erosion monitoring system (see below) at the head of one of the largest river systems in the UK, in a relatively hostile and dynamic upland fluvial context - environments which are coming under increasing development pressures. Secondly, the existing intensive and extensive IH instrumentation provided detailed, continuous and spatiallydistributed data on the variables likely to be of key explanatory significance (e.g. river flow, water quality, precipitation type and intensity, air and ground temperatures, surface radiation loading). Thirdly, as a fully-staffed experimental facility, the project could benefit from on-site technical and scientific assistance, routine instrument maintenance, and datalogger downloading. Lastly, the availability of suspended-sediment and bedload transport data for the catchment since 1979 would allow the relationship between sediment released from channel sides during bank erosion events and downstream sediment fluxes to be explored in a future phase of the project.

Figure 1 shows the study area of this paper, which concentrates on the upper $35 \mathrm{~km}$ of the River Severn basin in upland mid-Wales, UK (catchment area $=380 \mathrm{~km}^{2}$ ). The uppermost part of the catchment at Plynlimon has been instrumented intensively as an experimental basin by the Institute of Hydrology since the late 1960s (see Kirby et $a l .$, 1991). The Upper Severn basin, receives up to 2400 $\mathrm{mm}$ of precipitation per annum, and rises to almost $700 \mathrm{~m}$ O.D (Lawler, 1987; Kirby et al., 1991). The basin is characterised by a flashy hydrological regime and experiences about 162 days of ground frost per annum. In the uppermost reaches, banks are formed in highly organic peaty sediments, with occasional sandy/gravelly lenses. Downstream from the Plynlimon experimental catchments, the lithology is dominated by Silurian slaty mudstones overlain by fine loamy or silty soils, or river alluvium. The channel geometry and flood plain alter considerably through the Upper Severn. The river begins a steep descent from the source on the Plynlimon massif at an altitude of $620 \mathrm{~m}$ (Kirby et al., 1991), and occupies an incised channel characterised by numerous step-pool and riffle-pool sequences. Below Llanidloes (Fig. 1), in what has been termed the 'piedmont zone' (Newson, 1986; Hooke and Redmond, 1989), the river begins to flow over an alluvial substrate, and a narrow flood plain appears.

\section{MANUAL BANK EROSION MEASUREMENTS}

Bank erosion was measured at seven sites: five of these were located in the upper Severn experimental catchment at Plynlimon and two, piedmont, sites further downstream, at Morfodion and Caersws (Fig. 1). Erosion rates were monitored with erosion pins arranged in a grid of 24 on the bank-face at each site (Lawler, 1993a). Pin measurements were made on 41 occasions over a two-year period (1993-1995), at regular intervals and also following major flow events. Some cross-sections were also established and resurveyed at intervals to pick up more substantial changes.

\section{THE PHOTO-ELECTRONIC EROSION PIN (PEEP)} SYSTEM

Such conventional, manual, field monitoring methods, however, reveal merely net change in the position of a sediment surface since the previous measurement. They do not quantify the precise temporal distribution of such bank geometry changes. This means that the exact bank response to individual flow or meteorological events is generally unknown. Clearly, process explanations and model building and testing will be enhanced when (a) the full episodicity of bank change is detected, and (b) these specific erosion and deposition events are matched up to continuous information on the temporal fluctuations in the suspected driving forces.

To address these problems, therefore, the recently developed automatic Photo-Electronic Erosion Pin (PEEP) system (Lawler, 1991; 1992b) was deployed. This novel technique provides quasi-continuous data on the magnitude, frequency and timing of individual erosion and deposition events on river banks, gully walls, tidal creeks, mudflats, beaches, dunes or soil erosion plots etc. (Lawler, 1991; 1992a; 1992b; 1993b; Lawler and Leeks, 1992; Lawler et al., 1997b). The PEEP sensor consists of an array of photovoltaic cells designed for optical instrumentation purposes which are connected in series and then enclosed within a waterproofed, transparent, acrylic tube of $12 \mathrm{~mm}$ I.D. and $16 \mathrm{~mm}$ O.D. (Fig. 2) (Lawler, 1992b). The sensor generates a simple analogue voltage which is directly proportional to the total length of tube exposed to light and is designed to give approximately $1 \mathrm{mV}$ output for every $1 \mathrm{~mm}$ of erosion or accretion (though each sensor is individually calibrated). Networks (e.g. 4-8) of PEEP sensors are inserted into eroding or accreting sedi- 


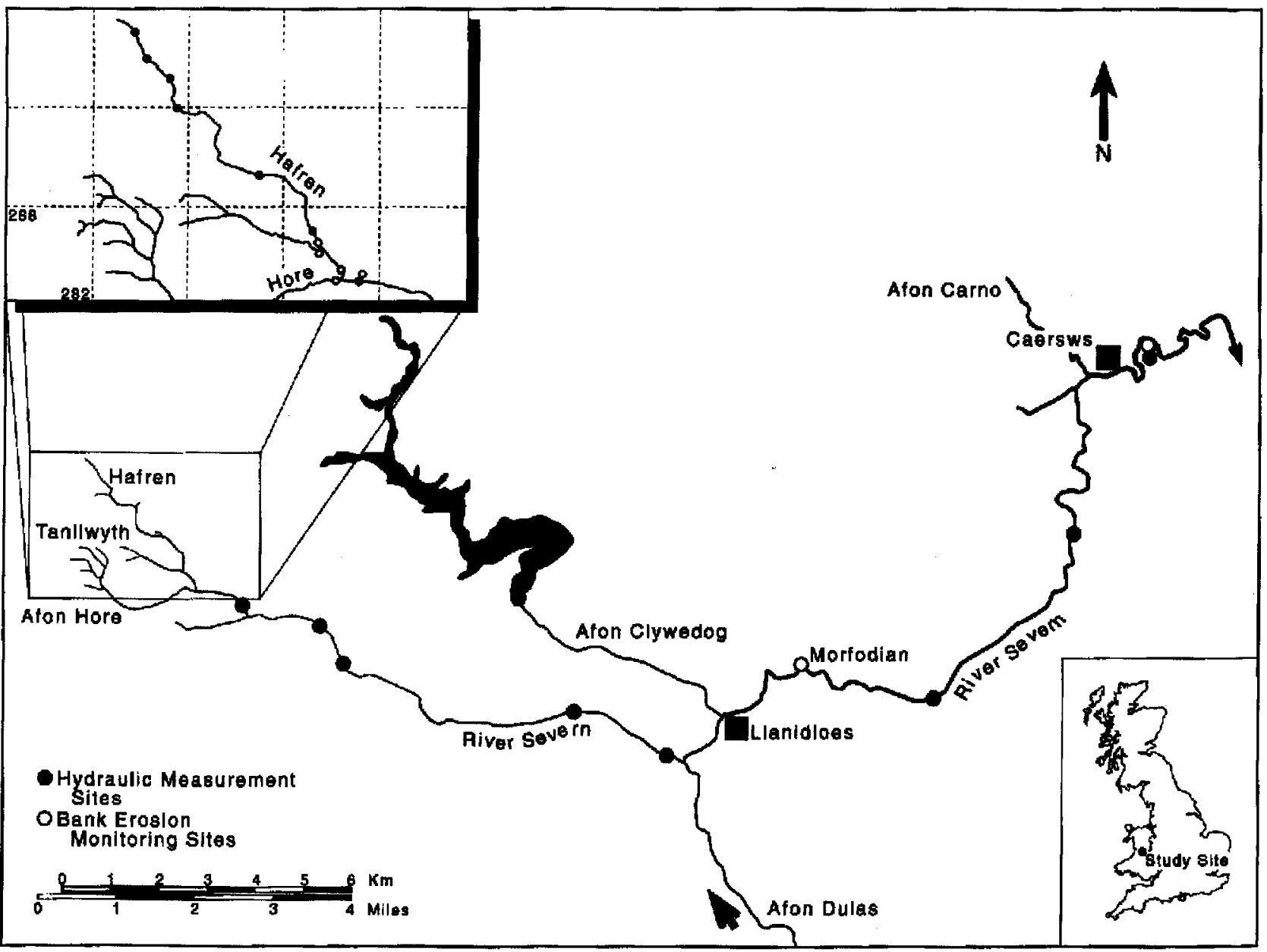

Fig. 1 Location of the study area: the Upper River Severn, Wales, UK, including the Plynlimon catchment. Site locations mentioned in the text also shown.

ment faces, and are then connected to a nearby datalogger (Fig. 2). Subsequent retreat of the surface exposes more PEEP cells to light which increases voltage outputs. Deposition around the tube reduces light reception and decreases voltage outputs. Recovered data thus reveal the magnitude, frequency and timing of individual erosion and deposition events much more precisely than has hitherto been possible (Lawler, 1992a).

A useful feature for field deployment is that a power supply is not required for PEEP sensors, as they are photovoltaic devices, and simply generate a voltage proportional to the intensity of incident light. Built-in reference cells allow normalization of outputs for varying light intensity. PEEP designs vary with the particular application and context (e.g. river bank, channel bar, hillslope). Prior laboratory calibration establishes relationships between PEEP voltage outputs and exposed tube lengths; the position of the sediment surface is generally known under ideal calibration conditions to within $\pm 2.5 \mathrm{~mm}$ with $95 \%$ confidence (Lawler, 1992b). More recent PEEP versions include thermistors to provide a temperature-sensing capa- bility at two different depths within the bank, and a second reference cell to confirm full exposure of the sensor during extreme events.

The PEEP sensors used in the Severn programmes were $400 \mathrm{~mm}$ long, and were equipped with an array of 10-12 photovoltaic diodes giving an 'active' length of $\sim 100 \mathrm{~mm}$. Campbell Scientific CR10 and Grant Instruments dataloggers were located within weatherproof housings on the floodplain. PEEP systems were installed at four sites: Tanllwyth (furthest upstream), Hore, Morfodion, and Caersws (furthest downstream) (Fig. 1). At each site, 4 PEEP sensors were installed in a grid format, two in the upper bank, and two in the lower bank. PEEP sensors were inserted into pre-drilled horizontal auger holes which were made long enough to accommodate anticipated future resetting (Lawler, 1992b). The cables were taken out of the back of the sensors through the bank interior (to avoid fouling the delicate bank surface) to the datalogger. To minimize disturbance effects, a column of two PEEPs shared a common vertical cable-access shaft (Fig. 2), and only the tips of the PEEP sensors were left protruding 


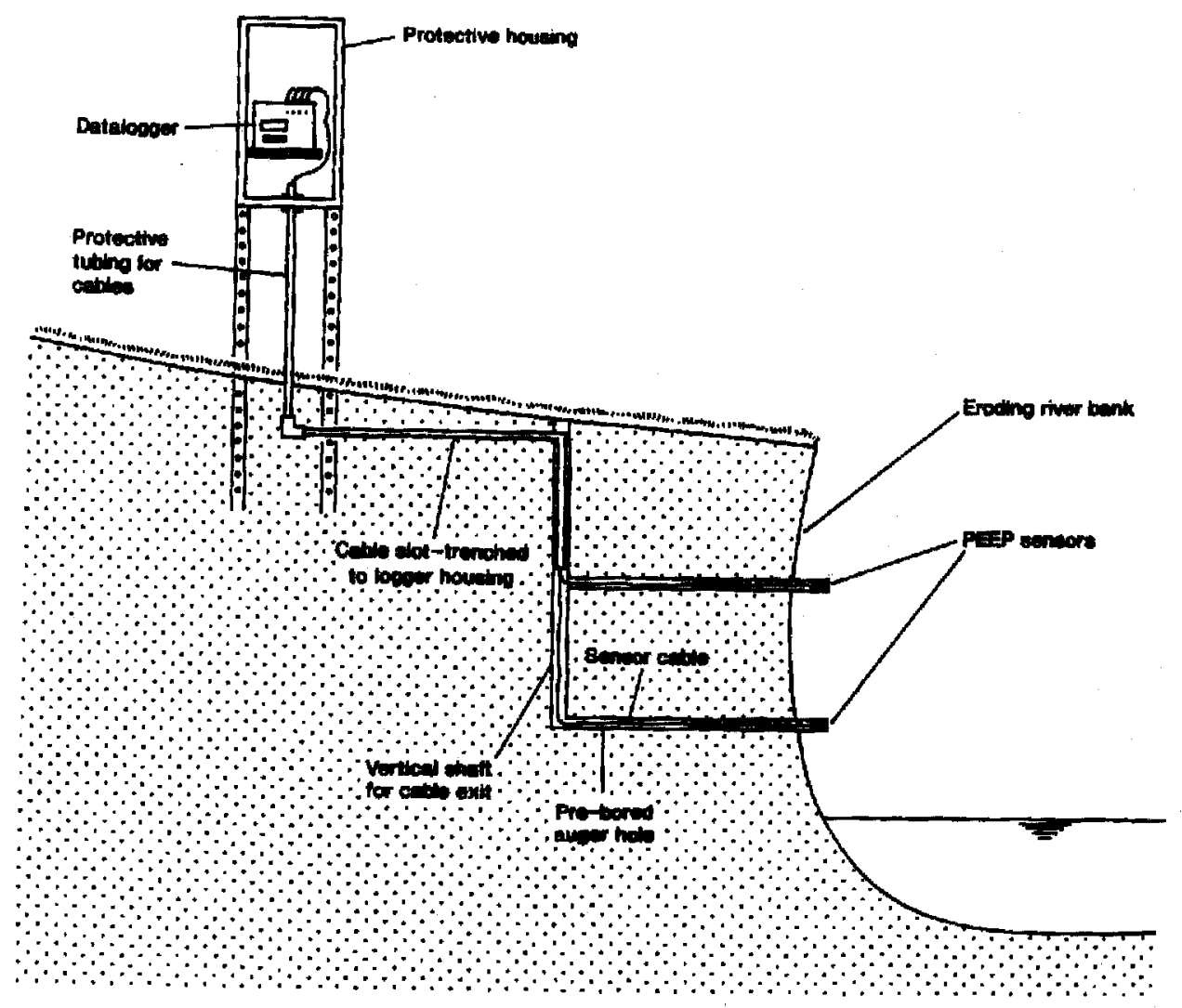

Fig. 2 Schematic illustration of a typical PEEP installation at an eroding river bank site. Normally four PEEP sensors are used, in two columns of tmo, to monitor the temporal distribution of erosion and deposition. These are embedded in a netmork of conventional erosion pins to detect spatial patterns of retreat.

from the bank, to leave the reference cell and cell No. 1 of the series visible. At each site, all PEEPs were connected to the same datalogger which scanned and recorded at 15min intervals. A pressure transducer and turbidity meter were also deployed at the lower two sites to provide continuous data on stage and suspended sediment concentrations (to be presented elsewhere). The IH Plynlimon site at Tanllwyth, first instrumented with PEEP systems in October 1990, boasts the longest-running quasicontinuous bank erosion dataset ever to be obtained, and, at an altitude of $350 \mathrm{~m}$ O.D., is one of the highest erosion monitoring sites in the UK.

PEEP techniques are not without limitations, however. For example, nocturnal events are not detected until the following morning, although the temporal resolution available is still much better than with traditional methods. (Data gaps at night can be plugged with programmed bursts of artificial light during datalogger scanning.) Also, as with traditional erosion pins, PEEP sensors are invasive, although their small size and installation method minimizes this. They may be less suitable for gravelly materials (difficult to install) or for mass failure situations where large blocks of material collapse into the flow, occasionally taking instrumentation with them. The addition of data transmitters to PEEP sensors will obviate the need for cabling and backfilled access holes (e.g. Fig. 2). Occasionally PEEP data can be lost or degraded under low-light conditions, or because the sensors have been covered by highly turbid water or trapped vegetation. Research is continuing to address these issues.

\section{MEASUREMENT OF CHANNEL HYDRAULICS}

Hydraulic measurements were made at fifteen study sites in the 1994-1996 period, between $0.04 \mathrm{~km}$ and $34.1 \mathrm{~km}$ downstream (Fig. 1), spaced at approximately logarithmic intervals to reflect the expected geometric increase of the channel capacity along the channel (Couperthwaite, 1997). Straight, single-thread reaches, undisturbed by tributary inflows and artificial structures, were chosen. A representative section was located within each reach and flow measurements were made at three flow exceedance frequencies, based upon a field estimation of flow magnitude defined by the ratio of water depth to bankfull elevation (Table 1). This ratio was later converted to exceedance frequencies and partitioned into low-, medium- and high- 
Table 1. A classification of flow based upon exceedance frequencies

\begin{tabular}{llll}
\hline Number & Flow classification & $\begin{array}{l}\text { Stage, } \mathrm{h} \\
\text { (bankfull }=100 \%)\end{array}$ & $\begin{array}{l}\text { Duration, } \mathrm{F} \\
\text { (frequency of occurrence, \%) }\end{array}$ \\
\hline 1 & High & $\mathrm{h} \geq 80 \%$ & $\mathrm{~F} \leq 10 \%$ \\
2 & Medium & $20 \leq \mathrm{h} \leq 80 \%$ & $10 \leq \mathrm{F} \leq 70 \%$ \\
3 & Low & $\mathrm{h} \leq 20 \%$ & $\mathrm{~F} \geq 70 \%$ \\
\hline
\end{tabular}

flows, using calculated discharges and historical flow records from local gauging stations (Table 1). The hydraulics of each section were measured at these three flow levels defined by the water stage relative to bankfull level (low flow $<20 \%$; medium flow $20-80 \%$; high flow $>80 \%$ ). For high flows, mean shear stresses for each reach have been estimated using measured bankfull hydraulic radius at bankfull levels, and surveyed flood plain slope values.

Each cross section was surveyed at the beginning of the study using either a Sokkisha level or a Zeiss Elta 4 Electro-Magnetic Distance Meter (Lawler, 1993a) and referenced to Ordnance Datum. Subsequent surveys of the section geometry involved detailed estimation of the geometrical properties of the water prism during flow measurement. Discharge was gauged with the velocity-area technique (Herschy, 1978), using the mean section variant (Shaw, 1988), by wading (Herschy, 1978; Bathurst, 1979), or from a boat (Beven and Carling, 1992). Logistic difficulties meant that high flows in the upper reaches could not be measured directly; hence, a trash line survey was conducted following a flood event in December 1996, and standard slope-area techniques applied. Discharge was estimated from nearby gauging stations or from a simple regression model generated from known discharges through the upper reaches during the event (Couperthwaite, 1997). The water surface was surveyed along each reach over a distance of 5-10 bankfull channel widths (centred on the study section), and slope was estimated from a simple linear regression fit of measured water elevation.

Point-value boundary shear stresses (e.g. Bathurst, $1979)$ and reach-mean shear stresses $(\tau)$ were computed as part of this catchment-scale survey of hydraulic properties, but only the latter are reported here. Reach-mean shear stress, $\tau$, in $N \mathrm{~m}^{-2}$, is calculated as $\lambda . R . S_{m}$, where $\lambda$ is the specific weight of water ( $9800 \mathrm{~N} \mathrm{~m}^{-3}$ for clear water), $R$ is the hydraulic radius (m), and $S_{w}$ is the water surface slope $\left(\mathrm{m} \mathrm{m}^{-1}\right)$. The channel edge water-surface slope was surveyed at a minimum of ten points over a distance of at least two channel widths upstream and downstream of the cross-section, using either a level and staff or an Electromagnetic Distance Meter (EDM).

\section{BANK MATERIAL CHARACTERISTICS}

As part of a detailed channel reconnaissance survey, bulk samples of bank material were taken at 30 systematicallyspaced sites approximately $1.5 \mathrm{~km}$ apart, in the upper 42 $\mathrm{km}$ of the Severn, beginning at the source. At each site, two samples were taken (upper and lower, at $25 \%$ and $75 \%$ of bank height) with a bulk density sampling tin, and transported to the laboratory for analysis of particle size distribution using wet-sieving and Malvern Instruments laser-sizer techniques. Only data on percent silt-clay are presented here, although full grain size distribution information will be published elsewhere.

\section{Results}

\section{BANK EROSION EVENTS}

PEEP results confirmed that, at all sites, bank erosion in the Upper Severn is accomplished largely through a series of large, discrete events, rather than as a slow, continuous process. Some examples from Tanllwyth and Morfodion (Fig. 1) indicate the highly episodic nature of the retreat process, the typical magnitude of erosional events, and the timing of erosion with respect to flow changes.

Figure 3 shows significant erosion occurring during, or shortly after, the storm event of 1 January 1991 in the small upland reach at Tanllwyth. The sudden rise in the diurnal cell series outputs of PEEP 902 on 2 January 1991, relative to the stable reference cell signal, represents bank retreat of over $70 \mathrm{~mm}$ in response to a single flow event (Fig. 3). Bank retreat at this PEEP site on this occasion was ten times the rate associated with an identically-sized flood a few days earlier on 20 December 1990 (Lawler and Leeks, 1992); pre-wetting of bank materials since the earlier event may have contributed subsequently to the later event. The week prior to the 20 December 1990 event was cold and dry, with rainfall of $57.9 \mathrm{~mm}$ falling between 6 and 11 December. The 2 January flood event, however, was the last in a sequence of flow rises over a 2-week period in which $260.1 \mathrm{~mm}$ of precipitation had fallen. Wolman $(1959$, p.204) found that fluvial bank erosion on the Watts Branch, Maryland, USA, was also especially severe if banks had first 'been thoroughly wetted'. Hooke 


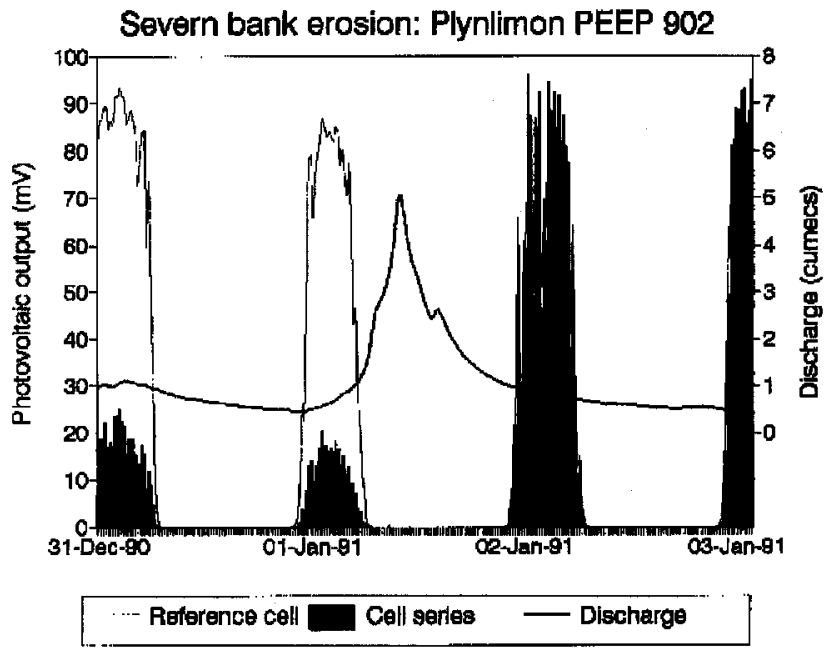

Fig. 3 Substantial erosion of at least $70 \mathrm{~mm}$ detected by PEEP sensor 902 cell series, in relation to the reference cell outputs, at Tanllmyth on 2 fanuary 1991 ( $\sim 1 \mathrm{mV}$ of PEEP output is equivalent to $1 \mathrm{~mm}$ of bank retreat).

(1979), too, identified elevated bank erosion rates for some Devon sites when Antecedent Precipitation Index values were high.

PEEP systems can also reveal the precise timing of daytime erosion events, information which can be used to suggest or discount likely processes. Figure 4, for example, shows that bank retreat is not always synchronized with the associated flow event at Tanllwyth. Here, for the first time, the precise moment of bank retreat has been detected. Note that the bank erosion event recorded by PEEP 903 (near the low-water level) is delayed in relation to the 20 December 1990 storm: the time of material removal is timed at $1330 \mathrm{~h}$ GMT on 22 December 1990. Within the previous 15 minutes, therefore (the logger scan interval), at least $80 \mathrm{~mm}$ of bank material had been removed, which fully exposed the active length of the PEEP sensor and increased cell series outputs to reference cell levels.

The delay of 48 hours between flow peak and erosion event in Fig. 4 suggests that fluid entrainment processes, which act virtually instantaneously, were not directly significant on this occasion. Instead, there is some anecdotal evidence in the literature to suggest that such fallingstage, delayed, erosion events are consistent with the 'drawdown' failure mechanism when lateral support on bank faces provided by the flood waters is withdrawn, leaving the saturated material to collapse en masse (Brunsden and Kesel, 1973; Hagerty et al., 1981; Kesel and Baumann, 1981). It may also be a 'pop-out' failure caused by progressively increasing pore water pressures in the bank material, as described by Bradford and Piest (1977).

Downstream of the experimental catchment, the range of bank erosion processes appears to increase. Along the Severn, in the piedmont zone around Morfodion (Fig. 1),

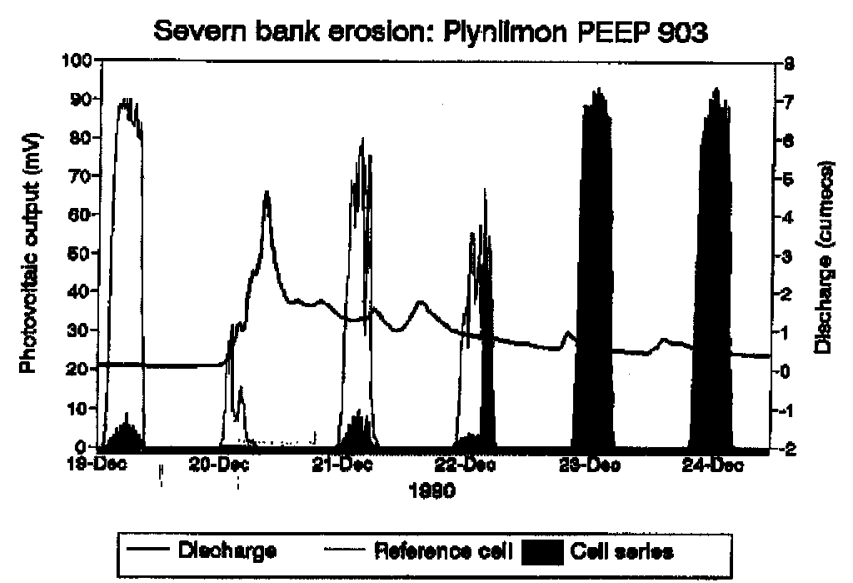

Fig. 4 An example of a delayed bank erosion event, as shown by the sudden rise in PEEP 903 cell series outputs at 1330 GMT on 22 December $1990(\sim 1 \mathrm{mV}$ of PEEP output is equivalent to $1 \mathrm{~mm}$ of bank retreat).

for example, bank erosion by cantilever collapse mechanisms has previously been identified as important by Thorne and Lewin (1979) and Thorne and Tovey (1981). These occur mainly on composite banks, i.e. those with a well-developed coarse basal layer overlain by much finer sediments. Thorne and Tovey (1981) suggested a threestage model. First, particles in the basal layer are entrained preferentially, because they are less resistant to fluid shear, and are subject to more frequent inundation. This, then, causes undercutting in the lower parts of the bank profile to create an overhang above. Finally, the overhanging block then collapses through shear, beam or tensile failure when it reaches critical mass or dimensions relative to the restraining forces at play.

However, no hard evidence of the timing of these cantilever failures with respect to the hydrograph have yet emerged-largely because of the absence of an automatic technique to detect bank change routinely as it happens. However, the PEEP system deployed at Morfodion has, for the first time, succeeded in detecting the precise moment of collapse of a small cantilever block. Figure 5A shows that, at 1415 GMT on 24 August 1993, the PEEP on the upper bank registers retreat of more than $50 \mathrm{~mm}$ : at the same moment, the PEEP sensor vertically below becomes completely buried with debris, as shown by the instantaneous zeroing of the PEEP cell series and reference cell outputs cell series (Fig. 5B).

\section{SPATIAL COMPARISON OF BANK EROSION EVENTS}

While a number of downstream comparisons of temporallylumped bank erosion rates exist (e.g. Hooke, 1977), the PEEP records here allow spatial comparisons to be effected at the event timescale. Seven bank erosion events of varying magnitude between 3 March 1993 and 28 December 1994 at four PEEP sites are presented in Fig. 6 in relation 


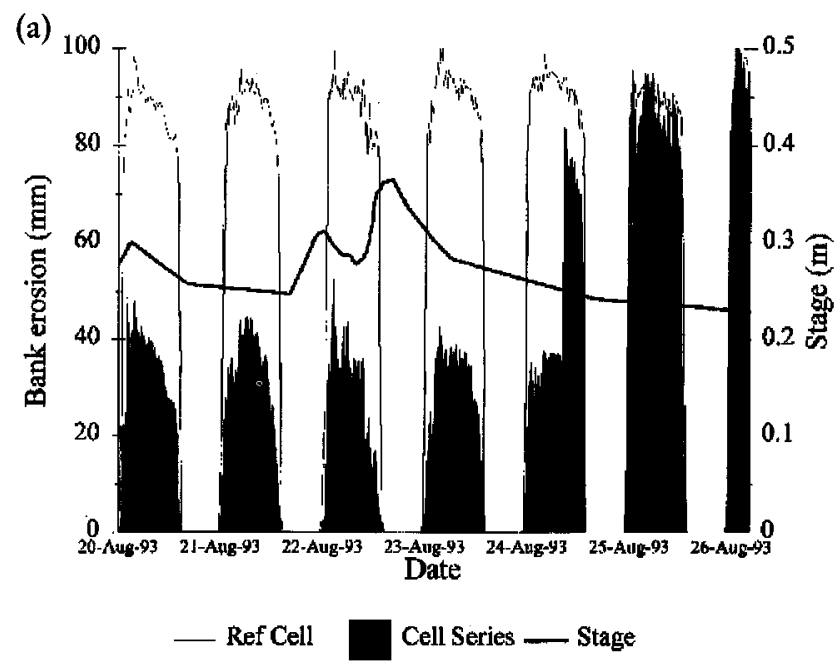

(b)

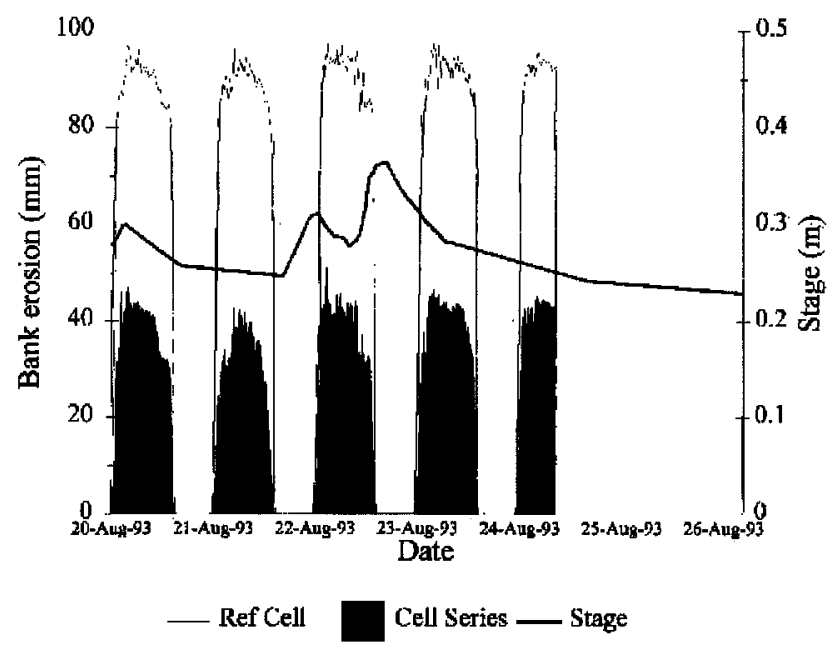

Fig. 5 An example of a cantilever bank collapse event at Morfodion detected by the PEEP system: (A) Sudden erosion at the upper PEEP site at 1415 GMT on 24 August 1993; (B) sudden deposition at the lower PEEP site at the same time $(\sim 1 \mathrm{mV}$ of PEEP output is equivalent to $1 \mathrm{~mm}$ of bank retreat).

to peak discharge achieved. A number of issues of spatial and temporal variability and downstream change are worth highlighting. In general, a good relationship exists between maximum flow attained and aggregated bank erosion amounts. In addition, very high rates of bank erosion can be achieved in this dynamic system: note the $104 \mathrm{~cm}$ of retreat associated with the flood of 21 December 1993. High variability in responses is also evident from the different amounts of bank retreat for floods of similar size in December 1993. Such variability is not consistent amongst sites, however: it is clear that, for the 21 December 1993 flood, erosion in the piedmont sites is substantially higher than in the upland sites while, for the similarly-sized flood of 12 December 1993, it is the upland sites where erosion is higher. Therefore, although bank erosion generally increases downstream, important differences emerge and, on the 12 December event, total bank erosion actually decreased downstream (Tanllwyth $=9 \mathrm{~cm}$; Caersws $=2$ $\mathrm{cm}$ ) (Fig. 6). Hence, relative activity rates of different sites is not consistent between floods. For example, Caersws, furthest downstream, emerges as more active than Morfodion on only four occasions: the reverse is true for the other three events. The reasons for such variation in the relative dynamism of the four sites will be investigated elsewhere but, apart from random effects, it probably reflects switches in the degree of bank sensitivity at the time of each flood, and the varying impacts of antecedent preconditioning from site to site. Clearly, this underlines the need to monitor bank erosion at the event timescale, as temporally-lumped information may conceal as much as it reveals about process operations.

\section{BANK EROSION RATES AND HYDRAULICS}

Figure 7 demonstrates that the downstream distribution of reach-mean shear stress, $\tau$, notwithstanding considerable reach-scale variability, is distinctly curvilinear. This is the result of the balancing out of conflicting non-linear trends in slope (which declines downstream), and hydraulic radius (which increases downstream), which are the key components of reach-mean shear stress computations. At all flows, $\tau$ peaks $1-6 \mathrm{~km}$ from the source (Fig. 7), a zone which lies at the heart of the Upper Severn catchment in Plynlimon. At low flows, $\tau$ increases from $15 \mathrm{~N} \mathrm{~m}^{-2}$ at 0.08 $\mathrm{km}$ to $30 \mathrm{~N} \mathrm{~m}^{-2}$ at $6 \mathrm{~km}$, before declining to $3 \mathrm{~N} \mathrm{~m}^{-2}$ at Caersws (Fig. 7). At medium flows, $\tau$ peaks at approximately $60 \mathrm{~N} \mathrm{~m}^{-2}$ between $0.8 \mathrm{~km}$ and $6 \mathrm{~km}$ from the source. Values for reach-mean shear stress at high flows simulated from MIKE 11 modelling runs (Couperthwaite, 1997) reproduce the same parabolic trend, with $\tau$ peaking at $800 \mathrm{~N} \mathrm{~m}^{-2}, 4 \mathrm{~km}$ downstream (Fig. 7). At around $10 \mathrm{~km}$ from the source, channel slope abruptly declines (Couperthwaite, 1997), which leads to clear reductions in reach-mean shear stress below that point (Fig. 7).

Discharge at medium flow levels in the Upper Severn increases rapidly from the source, from $0.03 \mathrm{~m}^{3} \mathrm{~s}^{-1}$ at 0.08 $\mathrm{km}$ to $4.44 \mathrm{~m}^{3} \mathrm{~s}^{-1}$ at $32.5 \mathrm{~km}$ (Fig. 8). The swift rise in discharge close to the source reflects the dense network of tributaries and enhanced orographic precipitation over the massif (Newson, 1976), which encourages rapid and efficient drainage. Discharge increases by three orders of magnitude $\left(0.001-1.0 \mathrm{~m}^{3} \mathrm{~s}^{-1}\right)$ within $5 \mathrm{~km}$ of the source at both low and medium flow levels; thereafter, the rate of increase slows considerably $\left(1-10 \mathrm{~m}^{3} \mathrm{~s}^{-1}\right)$.

Bank erosion rates increase downstream, when averaged over the whole site from erosion pin data, and integrated over the whole 2-yr study period (Fig. 8). Erosion rates are the lowest upstream of Tanllwyth, at $1.3 \mathrm{~cm} \mathrm{a}^{-1}$, rising to approximately $6 \mathrm{~cm} \mathrm{a}^{-1}$ at the downstream end of the experimental basin. Rates then increase strikingly for the 


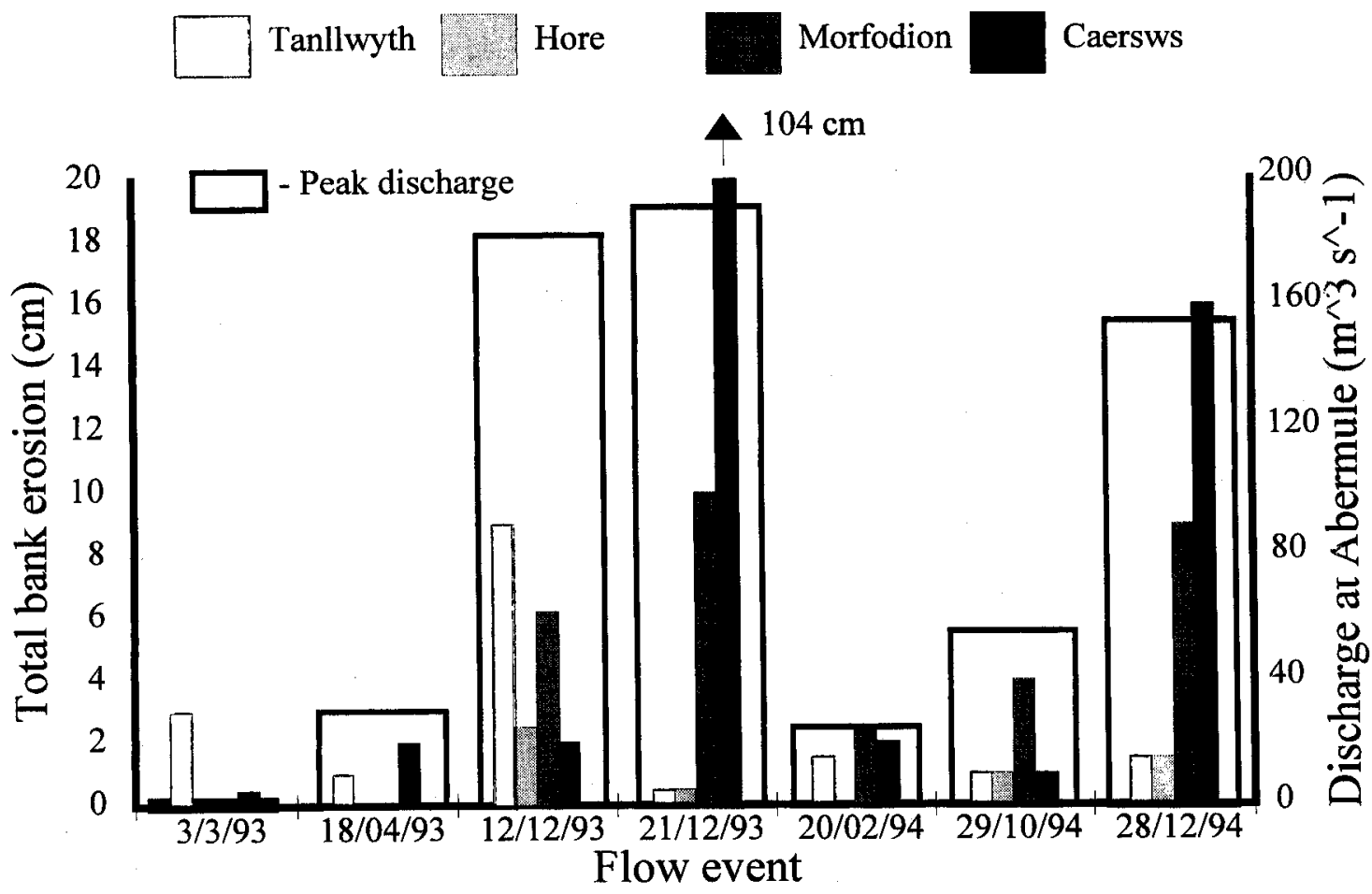

Fig. 6 The variability in bank erosion rate at four PEEP study sites during individual flow events. The peak discharge information is derived from the Abermule gauging station, located $20 \mathrm{~km}$ downstream from Caersws.

lower, piedmont, sites with $20 \mathrm{~cm} \mathrm{a}^{-1}$ and $46.0 \mathrm{~cm} \mathrm{a}^{-1}$ recorded at Morfodion and Caersws respectively (Fig. 8). Interestingly, the difference in bank erosion rates between the Plynlimon sites and the piedmont sites is more consistent with the increase in discharge downstream, than with the downstream change in reach-mean shear stress (Fig. 8).
Over the whole Upper Severn, it is perhaps curious that bank erosion rates increase downstream by more than an order of magnitude, while reach-mean shear stresses more than halve (Fig. 8). This may be because the energy actually available for bank erosion is much less in the upper reaches, where high bed roughness acts to dissipate energy

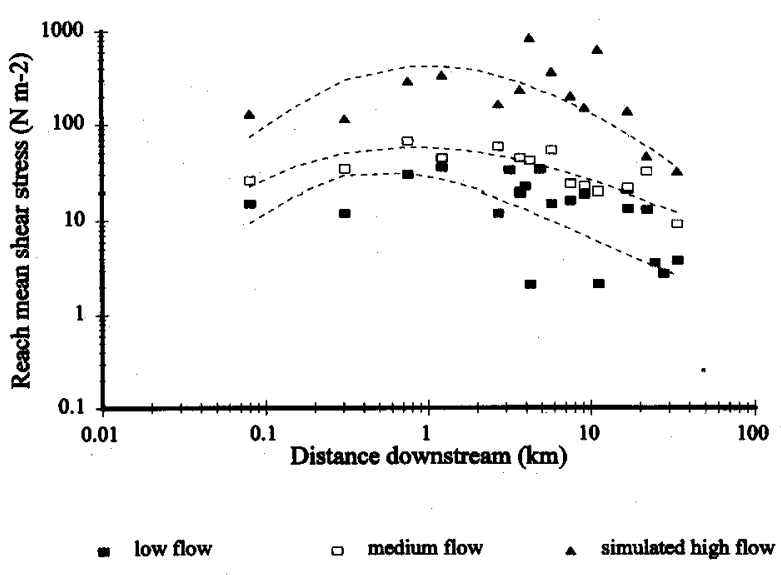

Fig. 7 The spatial and temporal variability of reach-mean shear stress along the Upper Severn. Predicted trend lines are marked as dashed lines. Note that for some sites more than one measurement is available.

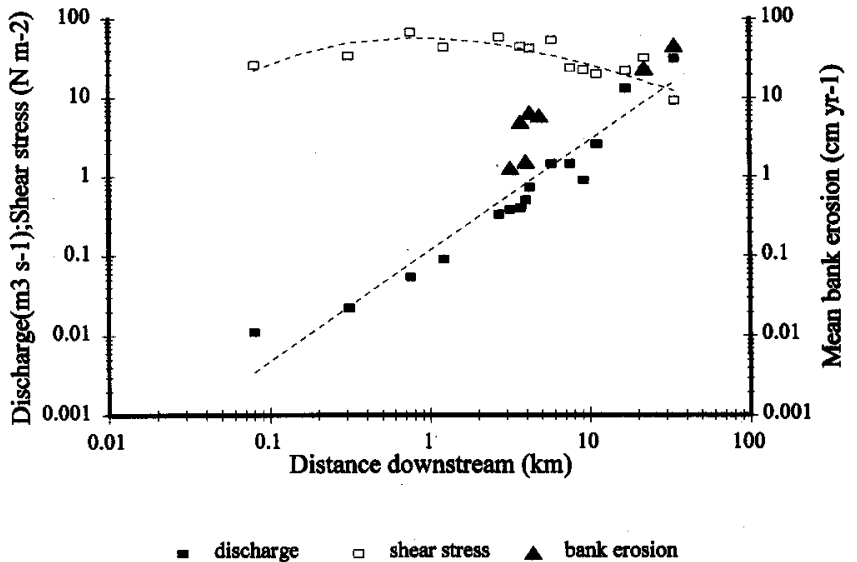

Fig. 8 Downstream change in bank erosion rates, reach-mean shear stress and discharge at medium flom levels in the Upper Severn. 
levels. It may also reflect changes in bank material characteristics between the upper and lower sites, and this is explored below.

\section{BANK MATERIAL CHARAC'TERISTICS}

Bank resistance is clearly an important influence. In the headwaters of the Severn, Fig. 9 shows that the upper and lower bank material is relatively coarse (silt-clay content $\sim 20 \%$ ). At the downstream piedmont sites (Morfodion and Caersws), however, (Fig. 9), the upper banks become much more fine-grained and cohesive (up to $80 \%$ siltclay), while the lower banks become much coarser (silt-clay contents $<10 \%$ ). Below Llanidloes, therefore (Fig. 1), the banks become increasingly composite, with the growing dominance of a gravelly basal unit in the bank profile.

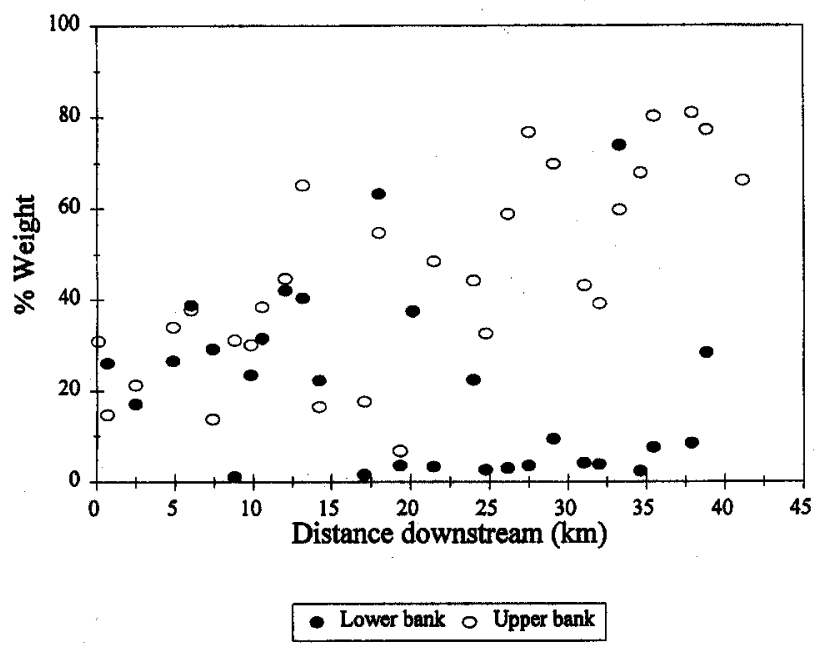

Fig. 9 The downstream variation in lower and upper bank material silt-clay content (\% meight) in the Upper Severn.

Composite bank profiles are essential to the cantilever failure mechanism (Thorne and Tovey, 1981; Thorne, 1982). This may also explain the downstream increase in bank erosion rates observed in Fig. 8: lower reach-mean shear stresses in the downstream piedmont sites offset by the development of such composite bank structures, which lead to an increasing tendency for cantilever failure. Cantilever collapse evidence was seen in abundance at Morfodion and Caersws in the present study (e.g. Fig. 5), confirming the observations of Thorne and his co-workers. Cantilever generation is a very efficient way of producing high bank erosion rates, because flow energy is required for sediment entrainment only in the lower part of the bank profile; gravitational forces complete the retreat cycle through geotechnical failure of the upper bank overhang. Thus, bank sedimentology appears to be as important as hydraulic changes in controlling both the dominant bank erosion processes and bank erosion rates in the Upper Severn. It also serves as a useful reminder that contempo- rary processes are heavily conditioned by past environmental conditions. For example, present-day hydraulics are, at least in part, controlled by inherited channel and valley form, and bank erosion processes are influenced by composite bank structures arising from longer-term valley alluviation sequences.

\section{Discussion}

\section{DOWNSTREAM CHANGE IN BANK PROCESSES}

Lawler (1992a) has argued that most bank erosion processes can be grouped into one of three categories: preparation or weathering processes, fluid entrainment mechanisms and mass failure processes. Lawler (1992a, 1995) further proposed that the relative dominance of these different process groups may alter downstream. His hypothetical, conceptual, model is supported by simple numerical experiments of downstream change in some of the variables which control the operation of these processes. The model suggests that, in the upper reaches of drainage basins, preparation processes (e.g. freeze-thaw effects (Lawler, 1993c)) are likely to be more effective because (a) shear stresses or stream powers, constrained by low hydraulic radii and low discharges respectively, are too low to promote erosion by fluid entrainment, and (b) banks are too small to be susceptible to mass failure, which is largely dependent upon bank heights exceeding critical instability thresholds (e.g. Osman and Thorne, 1988; Thorne and Osman, 1988; Lawler, 1992a). Further downstream in mid-basin, the optimum combination of watersurface slope, channel cross-section geometry and discharge is obtained (e.g. Lewin, 1982; 1983; Graf, 1983; Lawler, 1992a; Magilligan, 1992), and available stream energy is likely to peak. This is likely to be the zone where fluid entrainment processes dominate. Further downstream still, the significance of mass failures increases because bank heights and bank material clay contents increase-two factors which are well-known to promote slope instability (e.g. Rouse and Farhan, 1976; Thorne, 1982; Osman and Thorne, 1988). Although bank erosion by fluid entrainment and preparation processes occurred at all study sites here (along with the occasional mass failure), cantilever collapse occurred mainly at the two lowest sites, Morfodion and Caersws (Bull, 1996). As discussed above, this may also explain the dramatic increase in bank erosion rate at these piedmont sites (Fig. 8), and confirms suggestions made elsewhere (e.g. Newson, 1986; Leeks et al., 1988; Hooke and Redmond, 1989) that piedmont zones in general are highly active geomorphologically.

The suggestion that some spatial zonation of processes can be identified offers some-empirical support for the conceptual model of Lawler (1992a, 1995): however, the zoning of mass failure in the Upper Severn is thought to be driven significantly by bank material changes (i.e. the development of composite bank structures), rather than 
bank geometry alone. Also, the trend for reach-mean shear stress, although displaying a clear non-linear maximum as Lawler (1992a, 1995) hypothesized, peaks further upstream than the prediction. Some initial studies designed to field test aspects of this downstream change model have already been completed in the Severn (Harris, 1996; Bull, 1997; Couperthwaite, 1997), and a more detailed evaluation is underway in the River Swale (Grove, in prep). However, preliminary results indicate that, as theory and numerical simulations would suggest (Lawler, 1992a), a distinct, but overlapping, spatial zonation of bank erosion process groups can be identified as one moves downstream. If so, this has important implications for catchment sediment dynamics (as each process group is associated with a different timing of sediment injection into the flow), and erosion management, because different processes demand different strategies to control them.

\section{ADVANTAGES OF THE PEEP EROSION MONITOR- ING SYSTEM}

PEEP systems, because they detect activity automatically, allow a more precise picture of the temporal distribution of erosional and depositional activity to be established. Such information has enormous potential benefits. For example, it is useful in unravelling the problem of shifting threshold stresses required for erosion initiation (e.g. in response to biomediation effects (Black, 1997; Paterson, 1997) or prior weathering reactions (Lawler, 1992a)) -not least because the geomorphological impact of each hydraulic, hydrological or meteorological event can be ascertained. They also allow relationships between sediment supply and sediment transport to be defined more readily, thereby enhancing the definition of process linkages which control sediment fluxes at various time and space scales. PEEP sensors can also be linked to data telemetry platforms to generate real-time data which can help scheduling of fieldwork, provide early warnings of erosion problems, and assist the environmental manager to respond to issues.

It is likely that, once the fluvial community has available to it similarly precise data on the timing of mass failure events (e.g. Fig. 4), coupled with information on changes in river flow state, riparian hydrology and meteorological conditions, preferably from a number of contrasting fluvial environments for which the key geotechnical parameters are known, understanding of bank failure mechanics will be advanced considerably. However, significant opportunities have already been created with the arrival of automatic monitoring systems to field test the present generation of bank stability models developed by, for example, Osman and Thorne (1988), Thorne and Osman (1988), and Darby and Thorne $(1994,1996)$.

\section{Conclusions}

River channel adjustment occurs when the forces promoting erosion exceed those resisting it (Bull, 1979). This paper has sought to define three critical components of this relationship: bank response (dynamics of bank erosion events and rates); force (reach-mean shear stresses); and bank resistance (bank material silt-clay percentage). Bank erosion dynamics have been revealed through application of a novel automatic monitoring technique (the PEEP system), which can define the timing and impact of individual erosion events much more precisely than traditional methods. Hence, a more complete range of bank dynamic responses can now be investigated. As with so many environmental processes (e.g. turbidity), the availability of continuous or quasi-continuous information derived from automatic monitoring has proved fundamental to the identification of dynamics and processes. In particular, monitoring at high temporal resolution has suggested a change in the dominant mechanisms of bank erosion between the Plynlimon and the lower, piedmont, sites, and a recurrent switching in the relative activity rates of the different sites. In upstream areas, combinations of fluid entrainment and preparation processes seem to be most effective while at the downstream sites cantilever failures prevail.

Reach-mean shear stresses have been found to peak in the headwater reaches of the Severn at a range of flow levels. However, bank erosion rates are higher further downstream. This reflects an optimum combination at the downstream sites of composite bank structures and sufficiently high stream energy for significant lateral deformation of the channel boundary to take place. Of particular significance is the downstream change in bank sedimentology defined by field survey here, in which the most important aspect is the development in the lower reaches of a coarse, erodible, basal layer which is susceptible to fluvial scour, undercutting of the bank and the generation of cantilever collapse processes. These processes are very conducive to high bank erosion rates.

Understanding the driving variables in bank erosion systems, therefore, and their effective management, needs to go beyond evaluation of river flow properties at the reach scale. Instead, the most effective research and management strategies need to embrace additional components, including: (a) event-scale erosion monitoring using automatic instrumentation (as is common for most hydrological variables) to deliver information on episodic bank changes at high temporal resolution; (b) interpretations of such information in terms of hydrometeorological events significant for material pre-conditioning through pre-wetting, freezethaw and desiccation effects; (c) catchment-scale definitions of the key hydraulic variables as indices of the tractive forces applied to channel sides; and (d) multivariate bank resistance appraisal, either directly or through surrogate bank material characteristics which represent key promot- 
ing or retarding forces for specified bank erosion processes or process combinations.

\section{Acknowledgements}

This project was partly funded under NERC studentships to $\mathrm{LJB} / \mathrm{NMH} / \mathrm{JC}$, and a University of Birmingham Science Faculty Grant. The authors are very grateful to Graham Leeks, Steve Marks, Phil Hill, Alan Hughes and all the staff at the Plynlimon station of the Institute of Hydrology, for their support of this research. The field and logistics assistance provided by Richard Johnson and a large number of postgraduate students in the School of Geography at the University of Birmingham is greatly appreciated. Kevin Burkhill drew Figure 1. Great encouragement during this study has been provided by Heather, Jamie and Catherine Lawler.

\section{References}

Baker, V.R. and Costa, J.E. 1987. Flood power. In: Catastrophic Flooding (ed. by L. Mayer \& D. Nash). Allen \& Unwin, Boston, 1-21.

Bathurst, J.C. 1979. Distribution of boundary shear stress in rivers, In Rhodes, D. D. \& Williams, G.P. (Eds) Adjustments of the fluvial system, Kendall/Hunt Pub. Co., Dubuque, Iowa, 95-116.

Beven, K. and Carling, P.A. 1992. Velocities, roughness and dispersion in the lowland River Severn, in Carling, P.A. \& Petts, G.E. (Eds), Lowland Floodplain Rivers: Geomorphological Perspectives, Wiley, Chichester, UK, 71-93.

Black, K.S. 1997. Microbiological factors contributing to the erosion resistance in natural cohesive sediments, In: Burt, N. et al. (Eds) Cohesive Sediments, Wiley, Chichester, UK, 231-244.

Bradford, J.M. and Piest, R.F. 1977. Gullywall stability in loessderived alluvium, Soil Sci. Soc. Am. F. 41, 115-122.

Brunsden, D. and Kesel, R. 1973. Slope development on a Mississippi River bluff in historic time. 7. Geol., 81, 576-597.

Bull, W.B. 1979. Threshold of critical power in stream. Geol. Soc. Am. Bull. 90, 453-464.

Bull, L.B. 1996. Dynamics of fuvial sediment transport and riverbank sediment supply. Unpub. $\mathrm{PhD}$ thesis, University of Birmingham, $300 \mathrm{pp}$.

Church, M. and Slaymaker, O. 1989. Disequilibrium of Holocene sediment yield in glaciated British Columbia, Nature, 337, 452-454.

Couperthwaite, J.S. 1997. Downstream change in channel hydraulics along the River Severn, UK. Unpub. $\mathrm{PhD}$ thesis, University of Birmingham.

Darby, S.E. and Thorne, C.R. 1994. Prediction of tension crack location and river bank erosion hazards along destabilised channels, Earth Surf. Processes Landforms, 19, 233-245.

Darby, S.E. \& Thorne, C.R. 1996. Development and testing of riverbank-stability analysis, Proc. Am. Soc. Civ. Engrs, 7 . Hydraulic Engng, 122, 443-454.

Duijsings, J.J.H.M. 1987. A sediment budget for a forested catchment in Luxembourg and its implications for channel development, Earth Surf. Processes Landforms, 12, 173-184.

Graf, W.L. 1983. Downstream changes in stream power in the Henry Mountains, Utah. Ann. Ass. Am. Geogr. 73, 373-387.

Harris, N.M. 1996. The impact of scale on river bank erosion processes, Unpub. M.Phil. thesis, University of Birmingham

Hagerty, D.J., Spoor, M.F. and Ullrich, C.R. 1981. Bank failure and erosion on the Ohio River. Eng. Geol., 17, 141-158.

Herschy, R.W. (Ed) 1978. Hydrometry: Principles and Practice. Wiley, Chichester, UK.

Hooke, J.M. 1977. The distribution and nature of changes in river channel patterns: the example of Devon. In Gregory, $\mathrm{K}$. J. (Ed.) River Channel Changes, Wiley, Chichester, UK, 265-280.

Hooke, J.M. 1979. An analysis of the processes of river bank erosion. 7. Hydrol. 42, 39-62.

Hooke, J.M. 1980. Magnitude and distribution of rates of river bank erosion. Earth Surf. Processes, 5, 143-157.

Hooke, J.M. and Redmond, C.E. 1989. River-channel changes in England and Wales, 7. Inst. Wat. Engrs Manag., 3, 328-335.

Kesel, R.H. and Baumann, R.H. 1981. Bluff erosion of a Mississippi river meander at Port Hudson, Louisiana. Physical Geog., 2, 62-82.

Kirby, C., Newson, M.D. and Gilman, K. 1991. Plynlimon research: the first two decades. Institute of Hydrology Report no. 109, Wallingford, UK, $188 \mathrm{pp}$.

Lawler, D.M. 1987. Spatial variability in the climate of the Severn Basin: a palaeohydrological perspective. In: Palaeohydrology in Practice (ed. by K. J. Gregory, J. Lewin \& J. B. Thornes). Wiley, London, 49-78.

Lawler, D.M. 1991. A new technique for the automatic monitoring of erosion and deposition rates. Wat. Resour. Res. 27, 2125-2128.

Lawler, D.M. 1992a. Process dominance in bank erosion systems. In: Lomland Floodplain Rivers: Geomorphological Perspectives (ed. by P. A. Carling, \& G. E. Petts). Wiley, Chichester, UK, 117-143.

Lawler, D.M. 1992b. Design and installation of a novel automatic erosion monitoring system, Earth Surf. Processes Landforms, 17, 455-463.

Lawler, D.M. 1993a. The measurement of river bank erosion and lateral channel change: a review. Earth Surf. Processes Landforms Tech. E Software Bull, 18, 777-821.

Lawler, D.M. 1993b. Towards improved hypothesis testing in erosion-process research, in: Wicherek, S. (Ed.) Farmland Erosion in Temperate Plains, Environments and Hills, Elsevier, Amsterdam, 323-337.

Lawler, D.M. 1993c. Needle ice processes and sediment mobilization on river banks: the River Ilston, West Glamorgan, UK, F. Hydrol., 150, 81-114.

Lawler, D.M. 1994. Temporal variability in streambank response to individual flow events: the River Arrow, Warwickshire, UK. In: Variability in Stream Erosion and Sediment Transport (ed. by L. J. Olive, R. J. Loughran \& J. A. Kasby) (Proc. Canberra Symp., December 1994), 171-180. IAHS Publ. no. 224, 171-180

Lawler, D.M. 1995. The impact of scale on the processes of channel-side sediment supply: a model. In: Effects of Scale on Interpretation and Management of Sediment and Water Quality (ed. by W. Osterkamp), 175-184. IAHS Publ. no. 226.

Lawler, D.M., Thorne, C.R. and Hooke, J.M. 1997a . Bank erosion and instability, In Thorne, C.R., Hey, R.D. and Newson, M.D. (Eds) Applied Fluvial Geomorphology for River Engineering and Management, Wiley, Chichester, UK, 139-171

Lawler, D.M., Harris, N. and Leeks, G.J.L. 1997b. Automated monitoring of bank erosion dynamics: applications of the novel 
Photo-Electronic Erosion Pin (PEEP) system in upland and lowland river basins, In Wang, S.Y., Langendoen, E.J. and Shields; F.D., Jr. (Eds), Management of Landscapes Disturbed by Channel Incision, The University of Mississippi, Oxford, Mississippi, 249-255.

Lawler, D.M. and Leeks, G.J.L. 1992. River bank erosion events on the Upper Severn detected by the Photo-Electronic Erosion Pin (PEEP) system. In: Erosion and Sediment Transport Monitoring Programmes in River Basins (ed. by J. Bogen, D.E. Walling, \& T.J. Day). IAHS Publ. no. 210, 95-105.

Leeks, G.J., Lewin, J. and Newson, M.D. 1988. Channel change, fluvial geomorphology and river engineering: the case of the Afon Trannon, mid-Wales, Earth Surf. Processes 6 Landforms, $13,207-223$.

Lewin, J. 1982. British floodplains. In: Papers in Earth Studies (ed. by B.H. Adlam, C.R. Fenn \& L. Morris). Geo Books, Norwich, UK, 21-37.

Lewin, J. 1983. Changes of channel patterns and floodplains. In: Background to Palaeohydrology (ed. by K. J. Gregory). Wiley, Chichester, UK, 303-319.

Magilligan, F.J. 1992. Thresholds and the spatial variability of flood power during extreme events. Geomorphology 5, 373-390.

Newson, A.J. 1976. Some aspects of the rainfall of Plynlimon, Mid Wales. Institute of Hydrology Report no. 34, Wallingford, Oxfordshire, UK, 35 pp.

Newson, M.D. 1986. River basin engineering: fluvial geomorphology, 7. Inst. Wat. Engrs. Sci., 40, 307-324.

Odgaard, A.J. 1987. Streambank erosion along two rivers in
Iowa, Wat. Resour. Res., 23, 1225-1236.

Osman, A.M. and Thorne, C.R. 1988. Riverbank stability analysis. I: Theory, Proc. Am. Soc. Civ. Engrs, 7. Hydraulic Engineering, 114, 134-150.

Paterson, D.M. 1997. Biological mediation of sediment erodibility: ecology and physical dynamics, In: Burt, N. et al. (Eds) Cohesive Sediments, Wiley, Chichester, UK, 215-230.

Rouse, W.C. \& Farhan, Y.I. 1976. Threshold slopes in South Wales. Quart. 7. Engng. Geol, 9, 327-338.

Shaw, E. 1988. Hydrology in Practice. 2nd Edition. Van Nostrand Reinhold (International).

Thorne, C.R. 1982. Processes and mechanisms of river bank erosion. In: Gravel Bed Rivers (ed. by R.D. Hey, J.C. Bathurst \& C.R. Thorne). Wiley, New York, 227-271.

Thorne, C.R \& Lewin, J. 1979. Bank processes, bed material movement and planform development in a meandering river. In Rhodes, D.D. \& Williams, G.P. (Eds) Adjustments of the fluvial system, Kendall/Hunt Pub. Co., Dubuque, Iowa, 117-137.

Thorne, C.R. \& Osman, A.M. 1988. Riverbank stability analysis. II: Applications, Proc. Am. Soc. Civ. Engrs, 7. Hydraulic Engineering, 114, 151-172.

Thorne, C.R. \& Tovey, N.K. 1981. Stability of composite river banks. Earth Surf. Processes Landforms 6, 469-484.

Wang, S.Y., Langendoen, E.J. \& Shields, F.D., Jr. (Eds) 1997. Management of Landscapes Disturbed by Channel Incision, The University of Mississippi, Oxford; Mississippi, 1134 pp.

Wolman, M.G. 1959. Factors influencing erosion of a cohesive river bank. Am. 7. Sci., 257, 204-216. 